\title{
Congenital malformations of the central nervous system in spontaneous abortions
}

\author{
MICHAEL R. CREASY and EVA D. ALBERMAN \\ Paediatric Research Unit, Guy's Medical School, London SE1
}

\begin{abstract}
Summary. A study of 2620 pregnancies ending in spontaneous abortion revealed a CNS defect in 3.6\% of embryos and fetuses, and 3\% of all complete conceptuses. The type of malformation observed varied with the gestational age at expulsion, encephaloceles being predominant in earlier specimens, while more typical anencephalus and spina bifida were more common among later abortions.

Chromosome abnormalities were found in $40 \%$ of abortuses with CNS defects, but were almost entirely confined to those which were still at the embryonic stage of development. $53 \%$ of the latter were chromosomally abnormal, which is the same as the proportion found among embryos without a CNS malformation.

Using published life-tables of recognized pregnancies it was estimated that the prevalence of anencephalus, spina bifida, or related malformation (other than hydrocephalus), without a chromosome anomaly, is 5.3 per thousand conceptuses at the beginning of the eighth week of gestation. By comparing this with the prevalence in total births, it was further estimated that only $24 \%$ of these are born alive, with $54 \%$ aborting spontaneously and $22 \%$ being stillborn.
\end{abstract}

Most investigations into the prevalence and causes of central nervous system malformations have considered only livebirths and registered stillbirths. It has long been suspected that affected conceptuses are aborted disproportionately often, though we do not yet know what proportion is lost in this way. Moreover, it is not known how the aborted conceptuses compare with those that survive until birth from a pathological or aetiological point of view. Singh and Carr (1967) examined 168 spontaneously aborted embryos and fetuses and found two with a meningocele and one with an encephalocele (18 per thousand). They also found one abortus with an enlarged, eccentric spinal cord. Nishimura (1970), in Japan, found 49 CNS defects in 3715 induced abortions (13 per thousand), including 21 cases of exencephalus or myeloschisis (5.7 per thousand).

Data on these issues may be useful for several reasons. First, as prenatal diagnosis of high-risk pregnancies is now becoming increasingly common, knowledge of the prognostic significance of such a diagnosis will increase the accuracy of genetic

Received 21 January 1975. counselling. Second, all the important epidemiological studies in this field have been carried out on a selected group of affected infants, namely those reaching a potentially viable stage of development (for review, see Leck, 1974), and it is possible that associations have been missed. Third, these issues bear indirectly on the suggestion that much of the geographical, and possibly other, variation in birth prevalence may reflect variation between mothers, or even between pregnancies, in their tendency to abort affected conceptuses (Roberts and Lloyd, 1973).

\section{Methods}

With the co-operation of the medical and nursing staffs of gynaecological units in and around London, women who had a spontaneous abortion between September 1971 and April 1974 were interviewed regardless of the presumptive cause. In almost all cases the products of conception were collected for investigation, though often only curettings of these were available. When the conceptus was more than $30 \mathrm{~mm}$ in length (ie. a fetus), a macroscopical examination and dissection were carried out. Smaller specimens were studied under a binocular low-power microscope and kept in fixative for 
more detailed study later. Unless the specimen was extremely macerated, pieces of amnion, gonad, or other fetal tissue were taken for culture from explants, and chromosome preparations were made. According to the date of their last menstrual period, a few specimens were technically beyond the gestational age limit for abortions (27 weeks), but were included because they were extremely small for their dates.

\section{Results}

\section{Prevalence}

The 2620 pregnancies (2582 singleton and 38 twin) which were studied included 995 complete, organized fetuses in which any gross malformation present could have been detected. $36(3.6 \%)$ were found to have a lesion of the CNS (Table I). However, a further 221 specimens were intact empty sacs or severely disorganized embryos, making a total of 1216 specimens which could be examined. The crude prevalence of these CNS defects is therefore estimated as $36 / 1216$, or $3 \%$, among testable abortuses in the London area in the early 1970's.

TABLE I

\section{OUTCOME OF 2620 SPONTANEOUS ABORTIONS}

\begin{tabular}{l|r}
\hline Total pregnancies studied & 2620 \\
Twin pregnancies & +38 \\
Total conceptuses & 2658 \\
No recognizable fetus or sac & -810 \\
Incomplete fetus or ruptured sac & -632 \\
Complete fetus or intact sac & 1216 \\
Disorganized embryo or empty sac & -221 \\
Complete, organized fetus & 995 \\
With CNS malformation & -36 \\
With other malformation & -38 \\
Apparently normal fetus & 921 \\
\hline
\end{tabular}

This will be compared with the prevalence at birth in a subsequent section.

\section{Types of malformation}

A wide range of CNS malformations was observed, often in association with other anomalies, notably cleft-palate (Table II and Appendix). Four affected specimens had multiple anomalies, in one case those of Meckel's syndrome (case 16). Another (case 3) was a monozygotic twin, whose cotwin had identical malformations with the exception of the CNS defect-a myelomeningocele.

The type of CNS malformation appeared to vary with the gestational age at expulsion (Table III). Encephaloceles predominated among the younger abortuses. These were mostly small in relation to the size of the head, and in many cases it was difficult or impossible to decide whether the brain protruded through the fissum, or whether the malformation was strictly a cranial meningocele. All such lesions have been described as encephaloceles. Typical anencephalus was seen only in older abortuses, while exencephalus was found in those of intermediate age. One specimen with anencephalus and one with a large encephalocele had reputed ages of 29 and 28 weeks, respectively, but they, like a few others, were counted as abortions because of their size (see methods section).

\section{Chromosomes}

The chromosome constitution was determined for 25 of the 36 affected abortuses, and $10(40 \%)$ were found to have a chromosome abnormality (Table IV). The corresponding figure for 544 karyotyped embryos and fetuses without a CNS lesion was $13 \%$.

TABLE II

MALFORMATION IN FETUSES WITH A CNS DEFECT

\begin{tabular}{|c|c|c|c|}
\hline CNS Malformation & $\begin{array}{c}\text { No Other } \\
\text { Malformation }\end{array}$ & $\begin{array}{c}\text { Malformation of } \\
\text { Other System }\end{array}$ & Total \\
\hline Spina bifida (sb) & 2 & 1 cleft palate & 5 \\
\hline Encephalocele & 11 & $\begin{array}{l}4 \text { cleft palate } \\
1 \text { MSA* } \\
1 \text { talipes }\end{array}$ & 17 \\
\hline $\begin{array}{l}\text { Encephalocele + sb } \\
\text { Exencephalus } \\
\text { Exencephalus + sb }\end{array}$ & $\begin{array}{l}1 \\
5 \\
0\end{array}$ & 1 pulmonary & $\begin{array}{l}1 \\
5 \\
1\end{array}$ \\
\hline $\begin{array}{l}\text { Exencephalus acrania }+\mathrm{sb} \\
\text { Anencephalus } \\
\text { Anencephalus with cervical retroflexion }+\mathbf{s b}\end{array}$ & $\begin{array}{l}1 \\
1 \\
0\end{array}$ & $\begin{array}{l}\text { nypoplasta } \\
0 \\
0 \\
1 \text { bilat. flexion } \\
\text { deformity of the } \\
\text { fingers }\end{array}$ & $\begin{array}{l}1 \\
1 \\
1\end{array}$ \\
\hline $\begin{array}{l}\text { Craniorachischisis } \\
\text { Hydrocephalus } \\
\text { Cyclopia }\end{array}$ & $\begin{array}{l}2 \\
0 \\
1\end{array}$ & $1 \mathrm{MSA}^{*} \begin{array}{l}0 \\
0\end{array}$ & $\begin{array}{l}2 \\
1 \\
1\end{array}$ \\
\hline Total & 24 & 12 & 36 \\
\hline
\end{tabular}

- Multi-system anomalies. Full details in appendix. 
TABLE III

TIME OF EXPULSION OF FETUSES AND EMBRYOS WITH CNS DEFECTS

\begin{tabular}{|c|c|c|c|c|c|c|c|}
\hline \multirow{2}{*}{ CNS Defect } & \multicolumn{6}{|c|}{ Gestational Age (wk) } & \multirow{2}{*}{ Total } \\
\hline & $<12$ & $12-15$ & $16-19$ & $20-23$ & $24-27$ & $>27$ & \\
\hline $\begin{array}{l}\text { Spina bifida } \\
\text { Encephalocele } \\
\text { Exencephalus } \\
\text { Exencephalus acrania } \\
\text { Anencephalus } \\
\text { Craniorachischisis } \\
\text { Hydrocephalus } \\
\text { Cyclopia }\end{array}$ & $\begin{array}{l}1 \\
5 \\
1 \\
0 \\
0 \\
0 \\
0 \\
1\end{array}$ & $\begin{array}{l}1 \\
9 \\
1 \\
1 \\
0 \\
1 \\
0\end{array}$ & $\begin{array}{l}1 \\
3 \\
2 \\
0 \\
0 \\
0 \\
1 \\
0\end{array}$ & $\begin{array}{l}1 \\
0 \\
1 \\
0 \\
0 \\
0 \\
0 \\
0\end{array}$ & $\begin{array}{l}1 \\
0 \\
1 \\
0 \\
1 \\
1 \\
0 \\
0\end{array}$ & $\begin{array}{l}0 \\
1 \\
0 \\
0 \\
1 \\
0 \\
0 \\
0\end{array}$ & $\begin{array}{r}5 \\
18 \\
6 \\
1 \\
2 \\
2 \\
1 \\
1\end{array}$ \\
\hline Total & 8 & 13 & 7 & 2 & 4 & 2 & 36 \\
\hline
\end{tabular}

TABLE IV

CHROMOSOME CONSTITUTION OF 995 COMPLETE FETUSES AND EMBRYOS

\begin{tabular}{c|c|c|c|c}
\hline \multirow{2}{*}{ Fetus } & \multicolumn{3}{|c|}{ Karyotype } & Total \\
\cline { 2 - 5 } & Unknown & Normal & Abnormal & \\
\hline $\begin{array}{l}\text { With CNS defect } \\
\text { Without CNS defect }\end{array}$ & 11 & 15 & 10 & 36 \\
\hline Total & 426 & 480 & 64 & 959 \\
\hline
\end{tabular}

However, as the proportion of abortuses that have chromosomal aberrations is known to decrease sharply with increasing gestational age (Alberman and Creasy, 1975; Boué and Boué, 1969) a crude comparison, without allowance for the differing gestational age structure of the two sub-groups, would not be justified.

Of the 12 (of 35) CNS-defect specimens that exceeded $30 \mathrm{~mm}$ in crown-rump length, only one was shown to be chromosomally abnormal-a hydrocephalic triploid $(69, \mathrm{XXX})$. Of the 12,4 could not be examined chromosomally-spina bifida (2), exencephalus (1), anencephalus (1). The remaining 7 were chromosomally normal-encephalocele (3), exencephalus (2), anencephalus (1), and craniorachischisis (1). The chromosome abnormality rate is thus 1 in 8 among the large affected specimens, not significantly different from the rate of $4 \%$ (17 out of 454 ) among specimens of the same length without a CNS defect.

Chromosome anomalies were much more common in specimens that were not more than $30 \mathrm{~mm}$ long, whether maldeveloped or not (Table V). $53 \%$ of all those that could be examined were chromosomally abnormal, irrespective of whether they possessed a CNS defect or not. The affected subgroup included cases of sex chromosome monosomy, autosomal trisomy, triploidy and, in one specimen, an XXY sex chromosome complement with an additional F-like autosome $(48, \mathrm{XXY},+\mathrm{F})$. Autosomal trisomy accounted for $39 \%$ of the aberrations in the morphologically normal embryos, but only 2 out of $9(22 \%)$ in those with a CNS defect. The former group included trisomies of the C, D, E, and $\mathrm{G}$ group autosomes, the latter two being the most common. Both the trisomic embryos with a CNS defect had an extra member of the $\mathrm{D}$ group, and also cleft palate.

\section{Sex}

Of the fetuses which were past the embryonic stage of development (taken as those greater than $30 \mathrm{~mm}$ long) 5 were female, 5 were male, and 2 were of uncertain sex (Table VI). Those with anencephalus, craniorachischisis, or spina bifida

TABLE V

CHROMOSOME CONSTITUTION OF 107 EMBRYOS $\leqslant 30 \mathrm{~mm}$ CR

\begin{tabular}{l|c|c|c|c|c|c|c}
\hline \multirow{2}{*}{ CNS defect } & \multicolumn{7}{|c|}{ Chromosome Constitution } \\
\cline { 2 - 8 } & Normal & $45, \mathrm{X}$ & D Trisomy & $\begin{array}{c}\text { Other } \\
\text { Trisomy }\end{array}$ & Triploid & Other & Total \\
\hline Encephalocele & 5 & 4 & 2 & 0 & 0 & 1 & 12 \\
Exencephalus & 3 & 0 & 0 & 0 & 0 & 0 & 3 \\
Exencephalus acrania & 0 & 0 & 0 & 0 & 1 & 0 & 1 \\
\hline Spina bifida & 0 & 0 & 0 & 0 & 1 & 0 & 1 \\
\hline All CNS defects & 8 & 4 & 2 & 0 & 2 & 1 & 17 \\
\hline No CNS defect & 42 & 16 & 2 & 16 & 7 & 7 & 90 \\
\hline
\end{tabular}


TAVLE VI

SEX (MORPHOLOGICAL AND/OR CHROMOSOMAL) OF FETUSES, GREATER THAN $30 \mathrm{~mm}$ CROWN-RUMP, WITH A CNS MALFORMATION

\begin{tabular}{l|c|c|c|c}
\hline \multicolumn{1}{c|}{ Malformation } & Male & Female & Unknown & Total \\
\hline Spina bifida & 0 & 1 & 1 & 2 \\
Anencephalus & 0 & 2 & 0 & 2 \\
Craniorachischisis & 0 & 1 & 0 & 1 \\
Hydrocephalus & 0 & 1 & 0 & 1 \\
Exencephalus & 2 & 0 & 1 & 3 \\
Encephalocele & 3 & 0 & 0 & 3 \\
\hline Total & 5 & 5 & 2 & 12 \\
\hline
\end{tabular}

cystica included 4 females and no male, and the hydrocephalic was anatomically female. All 5 specimens with exencephalus and encephaloceles were male.

\section{Family history}

The obstetric histories of women who miscarried a conceptus with a CNS defect are summarized in Table VII. Two fathers had a mentally subnormal niece or nephew, one of whom was hemiplegic. The cousin of one father had a cleft palate, another father was the child of two deaf and dumb parents. The maternal aunt of one conceptus had a congenital heart defect. Only this abortus, of the five with a family history of congenital malformation, had a known chromosome abnormality $(45, \mathrm{X})$.

There was 1 anencephalic stillbirth among 35 previous births to the mothers of affected fetuses. As these births were derived from a total of 46 recognized pregnancies, the previous abortion rate is at least $11 / 46$, or $24 \%$.

\section{Estimate of prevalence}

Before the prevalence of CNS malformations in abortuses can be estimated and compared with the prevalence at birth, it is necessary to consider a number of points.

In many instances the products of miscarriage collected after hospital admission do not include an embryo or fetus. In some cases this is because the conceptus did not develop a recognizable embryo, but more often because the membranes have ruptured and the contents have been expelled. Obviously, when a ruptured sac, an incomplete fetus, or placental or maternal tissue only was received, diagnosis of malformation was impossible. Calculation of the proportion of CNS defects among complete fetuses only might well have overestimated their frequency in all pregnancies, because a number of conceptions consisted of an empty sac only, with no embryo, or of a disorganized mass of embryonic tissue. The frequency of CNS defects in pregnancies has, therefore, been calculated as a fraction of all 'complete' specimens, a complete specimen being defined as an intact empty sac, or an entire embryo or fetus, with or without its sac. This probably underestimated the true number of empty sacs, but the results could not be based on intact sacs alone, as this would have excluded almost all larger fetuses.

Another problem concerns the gestational age distribution of the sample. In any abortion series there is always a deficit of specimens lost at the earliest stages of pregnancy. As lesions of the CNS were found more frequently in such early specimens, an attempt was made to correct for this sampling bias by constructing a life-table. This would also allow a comparison of the figures for abortions with those for still- and livebirths. The basis of the life-table was derived from the Kauai pregnancy study (KPS) carried out on a Hawaiian island between 1953 and 1956 (French and Bierman, 1962). The island appears to have had extremely good antenatal facilities, and the stillbirth rate (less than 13 per thousand births) compares well with recent rates for South-East England (11 per thousand) and Greater London (12 per thousand), (Registrar General's figures for 1971). The KPS findings have been corroborated, at least for the period of gestation under consideration, by studies in Belfast in 1957 (Stevenson and Warnock, 1959) and in New York in 1958 (Shapiro, Jones, and Densen, 1962).

Column two of Table VIII includes all complete

TABLE VII

OBSTETRIC HISTORIES OF 36 MOTHERS OF ABORTUSES WHICH HAVE A CNS DEFECT

\begin{tabular}{|c|c|c|c|c|c|c|}
\hline $\begin{array}{l}\text { Not known } \\
\text { Normal } \\
\text { Abnormal } \\
\end{array}$ & $\begin{array}{l}11 \\
15 \\
10 \\
\end{array}$ & $\begin{array}{l}5 \\
8 \\
2 \\
\end{array}$ & $\begin{array}{l}14 \\
13 \\
19\end{array}$ & $\begin{array}{l}\mathbf{5} \\
\mathbf{4} \\
\mathbf{2}\end{array}$ & $\begin{array}{c}1 \text { anencephalic } \\
0 \\
0\end{array}$ & $\begin{array}{r}8 \\
9 \\
17\end{array}$ \\
\hline
\end{tabular}


TABLE VIII

ESTIMATED MORTALITY TABLE OF COHORT OF CONCEPTUSES COUNTED (NOTIONALLY) AT WEEK 8; ALL CAUSES (COL. 5) AND ASB-ASSOCIATED CAUSES (COL. 6)*

\begin{tabular}{|c|c|c|c|c|c|c|}
\hline 1 & 2 & 3 & 4 & 5 & 6 & 7 \\
\hline $\begin{array}{c}\text { Mode of Spontaneous } \\
\text { Termination of } \\
\text { Pregnancy, or } \\
\text { Expulsion of } \\
\text { Conceptus }\end{array}$ & $\begin{array}{l}\text { No. of } \\
\text { Complete } \\
\text { Specimens } \\
\text { Studies } \\
n\end{array}$ & $\begin{array}{l}\text { Observed } \\
\text { No. With } \\
\text { ASB } \\
\text { na }\end{array}$ & $\begin{array}{c}\text { Estimated ASB } \\
\text { Prevalence among } \\
\text { Terminations of } \\
\text { Indicated Category } \\
\text { (per 1000) } \\
1000 . \mathrm{n}_{\mathrm{a}} / \mathrm{n}\end{array}$ & $\begin{array}{c}\text { Estimated No. of } \\
\text { Conceptuses } \\
\text { (of a cohort of } \\
1000 \text { counted at } \\
\text { week 8) Expelled in } \\
\text { Way Indicated } \\
\text { N }\end{array}$ & $\begin{array}{l}\text { Estimated No. of } \\
\text { Conceptuses } \\
\text { (of cohort) } \\
\text { Expelled with ASB } \\
\text { in Way Indicated } \\
\quad N_{a}=N \cdot n_{a} / n\end{array}$ & $\begin{array}{l}\text { Estimated \% of } \\
\text { All ASB in Cohort } \\
\text { Expelled in Way } \\
\text { Indicated } \\
100 . \mathrm{N}_{\mathrm{a}} / 5.29\end{array}$ \\
\hline $\begin{array}{l}\text { Aborted at: } \\
8-11 \mathrm{wk} \\
12-15 \mathrm{wk} \\
16-19 \mathrm{wk} \\
20-23 \mathrm{wk} \\
24-27 \mathrm{wk} \\
\text { Stillborn: } \\
\text { ( }>27 \mathrm{wk}) \\
\text { Liveborn: }\end{array}$ & $\begin{array}{r}232 \\
316 \\
247 \\
239 \\
109 \\
\\
5741 \\
403725\end{array}$ & $\begin{array}{r}5 \\
7 \\
5 \\
2 \\
4 \\
\\
604 \\
605\end{array}$ & $\begin{array}{r}21.6 \\
22.2 \\
20.2 \\
8.4 \\
36.7 \\
105.2 \\
1.5\end{array}$ & 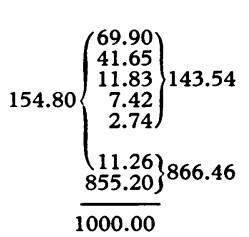 & $\begin{array}{c}4.01\left\{\begin{array}{l}1.51 \\
0.92 \\
0.24 \\
0.06 \\
0.10\end{array}\right\} 2.83 \\
\frac{1.28}{1.18} \\
\frac{5.29}{2.46}\end{array}$ & 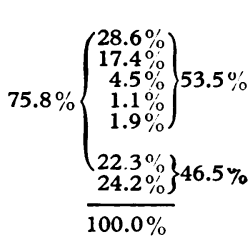 \\
\hline
\end{tabular}

* Data for outcome of pregnancy (col. 5) from French and Bierman (1962). ASB data for live and stillbirths from Carter and Evans (1973) and for spontaneous abortions from present study.

abortuses, as defined above, with a known gestational age between 8 and 27 weeks, inclusive, and a series of live- and stillbirths in Greater London reported by Carter and Evans (1973). Column three shows the number of these with a CNS defect. Only those abortuses with an ASB-type malformation (anencephalus, craniorachischisis, exencephalus, encephalocele, or spina bifida cystica), but no demonstrated chromosome anomaly, have been included, as only these were felt to be comparable with the classification of malformations used for births.

The proportion of affected conceptuses that is lost during each 4-week period of gestation was estimated, in each case, from the proportion with a malformation in the present study among the pregnancies at risk, as given by the life-table.

The calculations show that the prevalence of these malformations remains fairly constant among earlier fetal deaths, decreases towards the end of the previable period, and then increases to a maximum in late abortions and stillbirths. The overall rate among spontaneous abortions is estimated to be about 20 per thousand. This is one-fifth of that among stillbirths (105 per thousand), but is more than 13 times the rate among livebirths in the same area (1.5 per thousand) (Carter and Evans, 1973). The figures indicate that at the beginning of the eighth week of gestation, just over 5 per cent of all conceptuses have a recognizable malformation of the ASB type as defined above, but that $75 \%$ of these fail to be born alive, with more than two-thirds of this mortality occurring as spontaneous abortion (Tables VIII and IX). About $85 \%$ of term ASB
TABLE IX

ESTIMATED PREVALENCE OF ASB MALFORMATIONS AT DIFFERENT STAGES OF GESTATION FOR COHORT COUNTED (NOTIONALLY) AT WEEK 8*

\begin{tabular}{c|c|c|c}
\hline $\begin{array}{c}\text { Stage of } \\
\begin{array}{c}\text { Gestation } \\
\text { (beginning } \\
\text { of week) }\end{array}\end{array}$ & $\begin{array}{c}\text { Estimated } \\
\text { No. of } \\
\text { Surviving } \\
\text { Pregnancies } \\
\text { of Cohort } \\
\text { Counted at } \\
\text { Week 8 }\end{array}$ & $\begin{array}{c}\text { Estimated } \\
\text { No. of } \\
\text { Conceptuses } \\
\text { with ASB in } \\
\text { Cohort }\end{array}$ & $\begin{array}{c}\text { Estimated } \\
\text { Prevalence } \\
\text { of ASB in } \\
\text { Surviving } \\
\text { Pregnancies } \\
\text { of Cohort } \\
\text { (per 1000) }\end{array}$ \\
\hline 8 & 1000.00 & 5.29 & 5.29 \\
12 & 930.10 & 3.78 & 4.06 \\
16 & 888.45 & 2.86 & 3.22 \\
20 & 876.62 & 2.62 & 2.99 \\
24 & 868.83 & 2.56 & 2.84 \\
27 & 864.73 & 2.46 & \\
\hline
\end{tabular}

* Same sources as Table VIII.

infants are recorded as stillborn, though the true proportion must be lower, as many liveborn, malformed infants which live only a few minutes or hours are registered as stillbirths for humanitarian reasons.

\section{Discussion}

The results of this study show that the most common group of malformations in abortuses is a type apparently related to anencephalus and spina bifida. These latter form the most common category of malformation found at birth, in the U.K.

The gestationally older fetal deaths (those occurring from about the 20th week onwards) exhibit very similar lesions to those seen in births, while encephaloceles predominate among those expelled earlier in pregnancy. The small embryos will require microscopical examination of sections for accurate diagnosis of their anomalies, but this is 
TABLE X

RELATION BETWEEN TYPE OF MALFORMATION, SIZE OF EMBRYO OR FETUS, AND CHROMOSOME CONSTITUTION

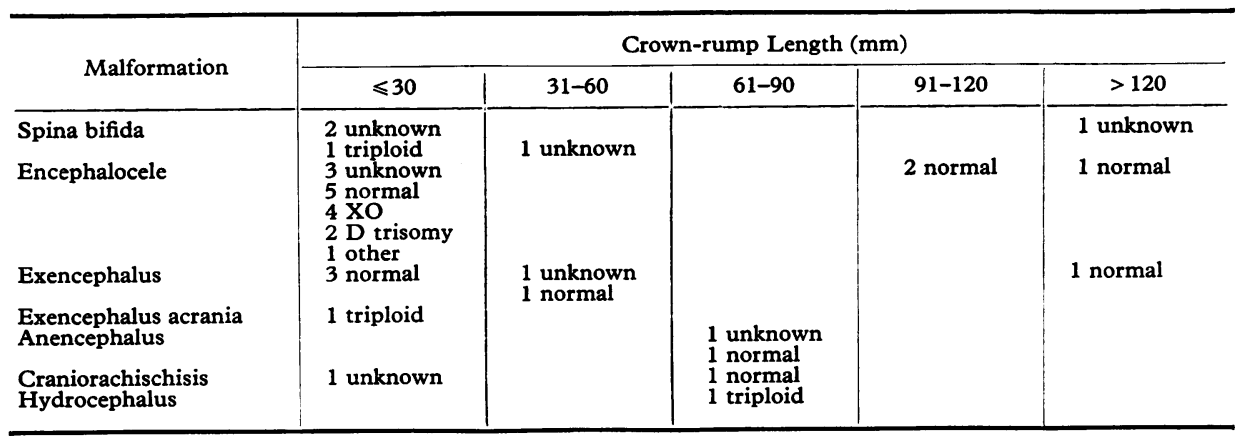

not necessary for the purposes of the present account, concerned as it is with the prevalence of CNS defects in general.

The qualitative difference between the types of CNS malformation associated with death in the earlier stages of pregnancy and those found in conceptuses which survive longer poses an important question: are these defects of different aetiology, or is one the forerunner of the others, seen at an earlier stage of development? In this connexion, the frequency of chromosome anomalies in malformed conceptuses during different periods of gestation is important.

The CNS anomalies found at birth are not generally considered to be associated with chromosome aberrations, but there is little information available. A study of 6 families with affected children revealed 1 father with a deleted chromosome 15 and another with an apparent short arm interchange between two D group chromosomes (Spellman, 1966). A mother with a mixoploid C chromosome trisomy (Stolte, Evers, and Bankenborg, 1964) and a father with a balanced translocation involving two $D$ group chromosomes (de Grouchy et al, 1964) have also been reported. In the infants themselves, Machin and Crolla (1974) found one anencephalic with a balanced translocation among 50 karyotyped perinatal deaths with ASB or hydrocephalus. An unbalanced translocation producing partial 2 trisomy (Lee et $a l, 1964)$ and an anencephalic male with XX sex chromosomes (Arias-Bernal and Jones, 1967) have been described. Trisomy $\mathrm{D}$, trisomy 18 , and triploidy are often associated with various CNS defects (Warkany, 1971; Niebuhr et al, 1972; Batts et al, 1972) but not usually those of the ASB type.

Of the larger affected ahortuses in the present series, only 9 were karyotyped and 1 was found to be chromosomally abnormal, but this specimen did not have an ASB malformation. Thus, in this respect also, the older abortuses may resemble the perinatal deaths. By contrast, $53 \%$ of the smaller affected abortuses (embryos $30 \mathrm{~mm}$ or less in length) had a chromosome aberration. However, these aberrations are found in this proportion of all abortuses of this size, so that it is difficult to decide whether the malformation was independent of, or secondary to, the chromosomal condition. The fact that $\mathrm{D}$ trisomy was the only trisomy found is interesting, because of the association between this condition and some CNS defects, as mentioned above. It seems possible that some chromosome conditions (possibly those involving $\mathrm{D}$ group chromosomes) may produce minor CNS lesions which do not develop into ASB malformations, while in other instances defects which do not produce such malformations coincide, by chance, with chromosome anomalies. Because both conditions have very high mortalities in early pregnancy, few survive until the perinatal period. If some embryos with abnormal chromosomes do have a true ASB type lesion, which is not a result of their karyotype, the prenatal mortality is higher than the estimate given.

It is evident that a family of malformations of the central nervous system, which includes anencephalus and spina bifida, is relatively common during the early stages of pregnancy, and that within this group, encephaloceles and exencephalus predominate. The former are often associated with chromosomal abnormalities, to which they might be secondary, though they are found in conditions such as sex chromosome monosomy, with which they are not usually associated at full term, and karyotypically normal conceptuses. Exencephalus, however, does not appear to have any links with chromosomal conditions. These two anomalies have the greatest prenatal loss, so that in the later stages 
of pregnancy anencephalus and spina bifida are the most numerous anomalies within the group (Table IX). The genetic and environmental factors producing these defects must be very complex and the group of malformations, and probably the subgroups within it, are probably heterogeneous in relation to them. It is possible that more can be learned of these aetiological factors by studying the malformation early in gestation, closer to the time of their appearance. Certainly it would be interesting to compare the loss through abortion in London with that from an area, such as South Wales or Ireland, where the prevalence at birth is higher.

The authors are indebted to Dr J. H. Renwick for his valuable help with the manuscript and $\mathrm{Dr} C$. O. Carter and Mrs K. Evans for allowing us access to their data. We also wish to thank the many gynaecologists who allowed us to study the products of conception of their patients with spontaneous abortion; Dr C. L. Berry and Dr G. A. Machin for examining a number of the specimens; Miss M. H. Elliott for interviewing many of the patients and much other assistance; and $\mathrm{Mr}$ J. A. Crolla and Mrs A. R. Grant for technical assistance.

The study was supported by grants from the Medical Research Council, Schering Chemicals Ltd., and the Spastics Society.

\section{REFERENCES}

Alberman, E. and Creasy, M. R. (1975). Factors affecting chromosome abnormalities in human conceptions. In Chromosome Variations in Human Evolution, pp. 83-95. Ed. by A. J. Boyce. Taylor and Francis, London.

Arias-Bernal, L. and Jones, H. W. (1967). An anencephalic male with XX sex chromosome complement. American fournal of Obstetrics and Gynecology, 99, 877-878.

Batts, J. A., Punnett, H. H., Valdes-Dapena M., Coles, J. W., and Green, W. R. (1972). A case of cyclopia. American fournal of Obstetrics and Gynecology, 112, 657-661.
Boué, J. G. and Boué, A. (1969). Fréquence des aberrations chromosomiques dans les avortements spontanés humains. Comptes Rendus Hebdomadaires des Séances de l'Académie des Sciences, 269, 283-288.

Carter, C. O. and Evans, K. (1973). Spina bifida and anencephalus in Greater London. Fournal of Medical Genetics, 10, 209-234.

De Grouchy, J., Brissaud, H. E., Repessé, G., and Lamy, M. (1964). Anencéphalie familiale et remaniement de deux chromosomes 1315. Comptes Rendus Hebdomadaires des Séances de l'Académie des Sciences, 2, 691-694.

French, F. E. and Bierman, J. M. (1962). Probabilities of fetal mortality. Public Health Reports, Washington, 77, 835-847.

Leck, I. (1974). Causation of neural tube defects: clues from epidemiology. British Medical Bulletin, 30, 158-163.

Lee, C. S., Bowen, P., Rosenblum, H., and Lindsay, L. (1964). Familial chromosome 2,3 translocation ascertained through an infant with multiple malformations. New England fournal of Medicine, 271, 12-16.

Machin, G. A. and Crolla, J. A. (1974). Chromosome constitution of 500 infants dying during the perinatal period. Humangenetik, 23, 183-198.

Niebuhr, E., Sparrevohn, S., Henningsen, K., and Mikkelsen, M. (1972). A case of liveborn triploidy $(69, \mathbf{X X X )}$. Acta Paediatrica Scandinavica, 61, 203-208.

Nishimura, H. (1970). Incidence of malformations in abortions. In Congenital Malformations, pp. 275-283. Ed. by F. C. Fraser and V. A. McKusick. Excerpta Medica, Amsterdam and New York. Registrar General (1973). Statistical Review of England and Wales for the Year 1971. I. Tables, Medical. H.M.S.O., London.

Roberts, C. J. and Lloyd, S. (1973). Area differences in spontaneous abortion rates in South Wales and their relation to neural tube defect incidence. British Medical fournal, 4, 20-22.

Shapiro, S., Jones, E. W., and Densen, P. M. (1962). A life table of pregnancy terminations and correlates of fetal loss. Milbank Memorial Fund Quarterly, 15, 7-45.

Singh, R. P. and Carr, D. H. (1967). Anatomic findings in human abortions of known chromosome constitution. Obstetrics and Gynecology, 29, 806-818.

Spellman, M.P.(1966). Chromosome investigations of anencephaly and other congenital CNS abnormalities in Cork. Irish fournal of Medical Science (sixth series), 489, 393-398.

Stevenson, A. C. and Warnock, H. A. (1959). Observations on the results of pregnancies in women resident in Belfast. Annals of Human Genetics, 23, 382-394.

Stolte, L., Evers, J., and Bankenborg, G. (1964). Possible trisomy in chromosome group 6-12 in a normal woman. Lancet, 2, 480481.

Warkany, J. (1971). Congenital Malformations. Year Book Medical Publishers, Chicago.

Details of fetuses with CNS malformations

\begin{tabular}{|c|c|c|c|c|c|}
\hline No. & $\begin{array}{c}\text { Gestational } \\
\text { Age (wk) }\end{array}$ & $\begin{array}{l}\text { Crown- } \\
\text { rump } \\
\text { Length } \\
\text { (mm) }\end{array}$ & $\begin{array}{c}\text { Anatomical } \\
\text { Sex } \\
\text { (Fetuses } \\
>30 \mathrm{~mm} \text { ) }\end{array}$ & Karyotype & Description \\
\hline
\end{tabular}

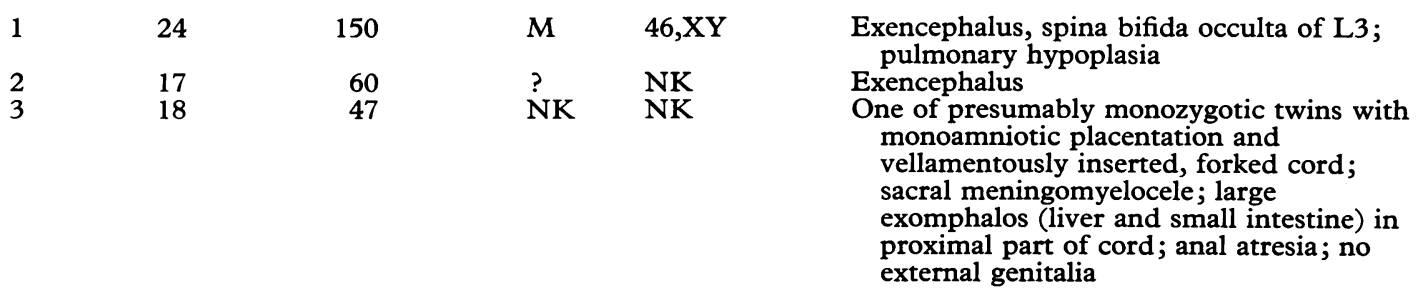

Exencephalus, spina bifida occulta of $\mathrm{L}_{3}$ external genitalia 
APPENDIX-continued

Details of fetuses with CNS malformations-continued

\begin{tabular}{|c|c|c|c|c|c|}
\hline No. & $\begin{array}{l}\text { Gestational } \\
\text { Age (wk) }\end{array}$ & $\begin{array}{l}\text { Crown- } \\
\text { rump } \\
\text { Length } \\
(\mathrm{mm})\end{array}$ & $\begin{array}{l}\text { Anatomical } \\
\text { Sex } \\
\text { (Fetuses } \\
>30 \mathrm{~mm} \text { ) }\end{array}$ & Karyotype & Description \\
\hline 4 & 29 & 80 & $\mathrm{~F}$ & NK & $\begin{array}{l}\text { Anencephalus with cervical retroflexion; } \\
\text { sacral meningocele; bilateral flexion } \\
\text { deformity of } 3 \text { rd finger }\end{array}$ \\
\hline 5 & 24 & 75 & F & $46, \mathrm{XX}$ & Anencephalus \\
\hline $\begin{array}{l}6 \\
7\end{array}$ & $\begin{array}{l}21 \\
24\end{array}$ & $\begin{array}{l}30 \\
67\end{array}$ & $\mathbf{F}$ & $\mathrm{NK}_{46 \mathrm{X}}$ & Spina bifida cystica \\
\hline 8 & 12 & 110 & $\mathbf{M}$ & $\begin{array}{l}40, \mathrm{XX} \\
46, \mathrm{XY}\end{array}$ & $\begin{array}{l}\text { Craniorachischisis } \\
\text { Occipital encephalocele }\end{array}$ \\
\hline 9 & 13 & 23 & & $46, X Y$ & Occipital encephalocele \\
\hline 10 & 28 & 160 & $\mathbf{M}$ & $46, X Y$ & $\begin{array}{l}\text { Occipital encephalocele; bilateral ulnar } \\
\text { polydactyly (6 digits); large cystic } \\
\text { kidneys; anomalous external genitalia } \\
\text { (Meckel's syndrome) }\end{array}$ \\
\hline 11 & 11 & 19 & & $47, \mathrm{XX},+\mathrm{D}$ & $\begin{array}{l}\text { Parieto-occipital encephalocele; bilateral } \\
\text { cleft lip }\end{array}$ \\
\hline 12 & 12 & 19 & & $\begin{array}{l}46, \mathrm{XX} \\
\text { NK }\end{array}$ & $\begin{array}{l}\text { Occipital encephalocele; bilateral cleft lip } \\
\text { Frontal encephalocele }\end{array}$ \\
\hline 14 & 19 & 110 & $\mathbf{M}$ & $46, X Y$ & $\begin{array}{l}\text { Fronto-parietal encephalocele; prominent } \\
\text { eyes; left talipes equinovarus }\end{array}$ \\
\hline $\begin{array}{l}15 \\
16\end{array}$ & $\begin{array}{r}7 \\
25\end{array}$ & $\begin{array}{r}20 \\
150\end{array}$ & $\mathbf{F}$ & $\begin{array}{l}\text { NK } \\
\text { NK }\end{array}$ & $\begin{array}{l}\text { Thoracic spina bifida cystica } \\
\text { Severe left scoliosis of thoracic and lumbar } \\
\text { regions of vertebral column, greatly } \\
\text { reducing left hemithorax; ectopia cordis; } \\
\text { exomphalos (liver and jejunum); right } \\
\text { pulmonary aplasia; enlarged right ovary; } \\
\text { reduction deformity of toes, probably left } \\
\text { talipes; fleshy appendage on sole of right } \\
\text { foot; Meckel's diverticulum; single } \\
\text { umbilical artery; lumbosacral } \\
\text { meningocele }\end{array}$ \\
\hline 17 & 22 & 19 & & $46, \mathrm{XX}$ & Exencephalus \\
\hline 18 & 13 & 20 & & $45, X$ & Parieto-occipital encephalocele \\
\hline 19 & 11 & 20 & & NK & Parietal encephalocele; spina bifida cystica \\
\hline 20 & 19 & 17 & & $45, \mathrm{X}$ & Frontal encephalocele \\
\hline 21 & 13 & 7 & & $69, \mathrm{XXY}$ & Exencephalus acrania; spina bifida cystica \\
\hline 22 & 10 & 22 & & NK & Cyclopia \\
\hline 23 & 10 & 29 & & $46, \mathrm{XX}$ & Frontal encephalocele \\
\hline 24 & 14 & 29 & & $46, X Y$ & Occipital encephalocele \\
\hline 25 & 14 & 30 & & $46, X Y$ & Exencephalus \\
\hline 26 & 18 & 43 & $\mathbf{M}$ & $46, X Y$ & Exencephalus \\
\hline 27 & 11 & 16 & & $48, \mathrm{XXY},+\mathrm{F}$ & Encephalocele \\
\hline 28 & 15 & 30 & & NK & Craniorachischisis \\
\hline 29 & 15 & 22 & & $69, \mathrm{XXY}$ & Lumbar spina bifida cystica; cleft palate \\
\hline 30 & 13 & 20 & & $45, \mathrm{X}$ & Parietal encephalocele \\
\hline 31 & 13 & 12 & & $47, \mathrm{XX},+\mathrm{D}$ & Frontal encephalocele; cleft lip \\
\hline 32 & 16 & 85 & F & $69, \mathrm{XXX}$ & Hydrocephalus; pulmonary hypoplasia ; \\
\hline 33 & 12 & 15 & & $45, \mathrm{X}$ & Pariental encephalocele \\
\hline 34 & 17 & 22 & & NK & Encephalocele; bilateral cleft lip \\
\hline 35 & 12 & 16 & & $46, \mathrm{XX}$ & Frontal encephalocele \\
\hline 36 & 9 & 28 & & $46, X Y q+$ & Exencephalus \\
\hline
\end{tabular}

NK = not known. 